\title{
A Study of Vertical Vibration of Ships
}

(2nd report)

\author{
By Katsuo Ohtaka*, Member. \\ Fujio Takaira*, Member. \\ Fukuden Hibino**, Member. \\ Masatomo Ohji*, Member.
}

\section{Summary}

Critical frequencies of the vertical vibration were calculated for 2 tankers, 4 high speed cargo liners and an ore-carrier, by means of the digital computation method described in the previous report(1).

The results were compared with the frequencies measured in the sea trials. Although there are some discrepancies between the computed and measured frequencies, the estimation of the frequencies of tankers and bulk carriers can be made with good accuracy by means of the empirical coefficient defined in this report.

Further the authors investigated the effects of the added virtual mass, effective breadth of the plating and the rotational inertia, the results of which showed that the rotational inertia can be neglected up to $6 \sim 7$ nodal model. For the ships having no longitudinal bulkheads such as bulk carriers and cargo ships, the effective breadth factor seems to affect the frequencies to some degree, but the detailed study on this subject will be investigated in a subsequent report. For the practical computation, Landweber's two-parametre family with Lewis' correction is fairly applicable to the estimation of virtual added mass.

\section{Contents}

1. Introduction.

2. Computation method and the numerical accuracy of the computer program.

3. Preparation of data for computation.

4. Comparison of computed with measured results. Empirical coefficient.

5. Discussions on the ship parametres.
A. Virtual added mass
B. Rotational inertia
C. Effective breadth

6. Conclusions and acknowledgement.

\section{Introduction}

Recently the application of digital computer technique to the ship vibration problem has been undertaken by many authors ${ }^{(2) \sim(7)}$. Their results are very useful and expiring to the people who are engaging in this field. The only regret from the designer's point of view is the fact that the ratio of calculated versus measured frequencies is considerably different.

To overcome this difficulty and to establish the practical estimation techique, the programme was 原稿受付 昭和 41 年 1 月 7 日

* Research engineer, Nagasaki Technical Institute, Mitsubishi Heavy Industries, Ltd.

** Engineer, Nagasaki Shipyard and Engine Works. M. H. I. Ltd. 
undertaken in the Mitsubishi Heavy Industries, Ltd., which includes the measurements of hull vibration in the sea trials and the computations of natural frequencies. A part of the results was already published in the lst report(1) in which 2 bulk carriers and 2 destroyers were dealt with.

This report is a continuation of the previous one and includes the results on 2 tankers, 3 cargo liners and an ore-carrier. Also are included the considerations on the effect of the virtual added mass, rotational inertia and effective breadth upon the natural frequency.

\section{Computation method and the numerical accuracy of the computer program.}

The details of the method were shown already in the previous report(1) and are omitted in this report. Some remarks on the computer program are as follows.

(1) Bending rigidity, shear rigidity and rotational inertia are taken into account.

(2) The ship's length overall is divided into many segments which are not necessarily equal length. The number of segments can be taken up to 70 .

(3) Within each segments the ship parametres such as weight, and rigidity are taken uniform.

(4) Computation outputs are ; natural frequencies and the correspondind deflections, bending slopes, bending moments and shear forces.

For the purpose of examining the numerical accuracy of the program, the calculations were made for the uniform free-free beam and the results are compared with theoretical one in Table 1 . Also are shown in Table 2 the comparisons of per centage errors of the present method with those of the other authors. It is seen from this table that, although the method by De Vries gives the least

Table 1 Comparison of computed natural frequencies with exact solution for uniform free-free beam.

\begin{tabular}{c|c|c|c|c|c|c|c}
\hline \multirow{2}{*}{$\begin{array}{c}\text { No. } \\
\text { of } \\
\text { Nodes }\end{array}$} & \multicolumn{3}{|c|}{ Bending Only } & \multicolumn{3}{c}{ Bending+Shear } \\
\cline { 2 - 8 } & $\begin{array}{c}\text { Exact } \\
\text { Solution }\end{array}$ & $\begin{array}{c}\text { Computer } \\
\text { Result }\end{array}$ & Error* & $\begin{array}{c}\text { Exact } \\
\text { Solution }\end{array}$ & $\begin{array}{c}\text { Computer } \\
\text { Result }\end{array}$ & Error* \\
\hline 2 & 50.82 & 50.82 & 0 & $\%$ & 46.49 & 46.48 & -0.02 \\
3 & 140.05 & 140.1 & 0.04 & 106.40 & 106.4 & 0 \\
4 & 274.67 & 274.9 & 0.08 & 171.63 & 171.7 & 0.1 \\
5 & 453.80 & 455.4 & 0.35 & 236.04 & 236.6 & 0.3 \\
6 & 677.91 & 680.0 & 0.31 & 299.17 & 300.6 & 0.5 \\
7 & 952.33 & - & - & 360.94 & 363.8 & 0.8 \\
\hline
\end{tabular}

* Error $=\frac{\text { Computer Result-Exact Solution }}{\text { Exact Solution }} \times 100 \%$

Table 2 Comparison of numerical errors of various authors* for the natural frequencies of uniform free-free beam.

\begin{tabular}{|c|c|c|c|c|c|c|c|c|}
\hline Author & \multicolumn{4}{|c|}{ Leibowitz } & \multirow{2}{*}{$\begin{array}{c}\begin{array}{c}\text { Vreug- } \\
\text { Denhil }\end{array} \\
\begin{array}{c}\text { Bending } \\
\text { Only }\end{array}\end{array}$} & \multirow{2}{*}{$\frac{\begin{array}{c}\text { De } \\
\text { Vries }\end{array}}{\begin{array}{c}\text { Bending } \\
\text { Only }\end{array}}$} & \multicolumn{2}{|c|}{ Present Authors } \\
\hline $\begin{array}{l}\text { Calculated } \\
\text { Condition }\end{array}$ & Bending & Only & Bending & Shear & & & $\begin{array}{l}\text { Bending } \\
\text { Only }\end{array}$ & $\begin{array}{l}\text { Bending } \\
\quad+\text { Shear }\end{array}$ \\
\hline $\begin{array}{l}\text { Divisions for } \\
\text { Calculation }\end{array}$ & $\begin{array}{l}20 \text { Equal } \\
\text { Divs. }\end{array}$ & $\begin{array}{l}40 \text { Eq. } \\
\text { Divs. }\end{array}$ & $\begin{array}{l}20 \text { Eq. } \\
\text { Divs. }\end{array}$ & $\begin{array}{l}40 \text { Eq. } \\
\text { Divs. }\end{array}$ & $\begin{array}{l}20 \text { Eq. } \\
\text { Divs. }\end{array}$ & $\begin{array}{l}20 \text { Eq. } \\
\text { Divs. }\end{array}$ & $\begin{array}{l}20 \text { Eq. } \\
\text { Divs. }\end{array}$ & $\begin{array}{l}20 \text { Eq. } \\
\text { Divs. }\end{array}$ \\
\hline 2-Node & $0.14^{\%}$ & $0.04^{\%}$ & $0.02^{\%}$ & & -2.9 & & & -0.02 \\
\hline $3-11$ & -0.3 & -0.04 & -0.6 & -0.1 & -2.0 & -0.004 & 0.04 & 0 \\
\hline $4-\quad 11$ & -1.2 & -0.3 & -1.4 & -0.4 & -4.2 & -0.01 & 0.08 & 0.1 \\
\hline $5-11$ & -2.5 & -0.6 & -2.4 & -0.6 & - & 0.04 & 0.35 & 0.3 \\
\hline $6-11$ & -4.2 & -1.0 & -3.5 & -0.9 & - & 0.09 & 0.31 & 0.5 \\
\hline $7-11$ & -6.9 & -2.1 & -4.9 & -1.2 & - & 0.21 & - & 0.8 \\
\hline $8-\quad 11$ & - & - & - & - & - & 0.45 & - & - \\
\hline
\end{tabular}

* Definition of error is the same as Table 1 . 
ror, the present method gives a fairly good results for practical use.

\section{Preparation of data for computation.}

The ships for which calculations were carried out are shown in Table 3, together with their particulars. Of these ships listed, ships $\mathrm{G}$ and $\mathrm{H}$ were described already in the previous report ${ }^{(1)}$, and are added here for completeness.

Table 3 List of ships investigated in this report

\begin{tabular}{|c|c|c|c|c|c|c|c|c|}
\hline \multirow{2}{*}{$\begin{array}{l}\text { Ship } \\
\text { Name }\end{array}$} & \multirow{2}{*}{ Type } & \multirow{2}{*}{$\mathrm{Lpp} \times \mathrm{B} \times \mathrm{D}(\mathrm{m})$} & \multicolumn{3}{|c|}{ Full load condition } & \multicolumn{2}{|c|}{ Test condition } & \multirow{2}{*}{$\frac{I_{V} x^{* * *}}{\left(m^{4}\right)}$} \\
\hline & & & $\mathrm{Cb}$ & $\mathrm{dm}^{*}(\mathrm{~m})$ & $\Delta^{* *}($ ton $)$ & $\mathrm{dm}^{*}(\mathrm{~m})$ & $\Delta^{* *}($ ton $)$ & \\
\hline A & Cargo Liner & $145 \times 19.5 \times 12.3$ & 0.667 & 8.82 & 17045 & 4.63 & 8100 & \\
\hline B & Do. & $145 \times 19.5 \times 12.3$ & 0.667 & 8.82 & 17045 & 6.24 & 11400 & $* * * *$ \\
\hline $\mathrm{C}$ & Do. & $145 \times 19.5 \times 12.3$ & 0.667 & 8.82 & 17045 & 8.35 & 15900 & \\
\hline $\mathrm{D}$ & Do. & $150 \times 23 \times 12.8$ & 0.559 & 9.342 & 18472 & $\begin{array}{l}4.952 \\
6.179\end{array}$ & $\begin{array}{r}8667 \\
11356\end{array}$ & 52.75 \\
\hline $\mathrm{E}$ & Tanker & $213 \times 30.5 \times 15.2$ & 0.801 & 11.485 & 61270 & $\begin{array}{r}8.34 \\
11.42\end{array}$ & $\begin{array}{l}43070 \\
61392\end{array}$ & 187.1 \\
\hline $\mathrm{F}$ & Do. & $218 \times 32.9 \times 15.6$ & 0.811 & 11.557 & 68933.5 & $\begin{array}{r}5.223 \\
11.155\end{array}$ & $\begin{array}{l}29030 \\
66289\end{array}$ & 212.03 \\
\hline G & Bulk Carrier & $192 \times 27.5 \times 16.1$ & 0.791 & 10.78 & 46130 & 5.43 & 21652 & 152 \\
\hline $\mathrm{H}$ & Bulk Carrier & $183 \times 27.4 \times 14.8$ & 0.813 & 14.8 & 41680 & 5.09 & 19900 & 115.46 \\
\hline I & Ore Carrier & $214 \times 30.8 \times 15.7$ & 0.816 & 11.637 & 64163 & 6.11 & 32167 & 198.3 \\
\hline Notes: & $\begin{array}{rl}* & \text { Mean draugh } \\
* * & \text { Displacement } \\
* * * & \text { Moment of ir } \\
* * * * & 44.03 \text { up to un }\end{array}$ & $\begin{array}{l}\text { of midship sec } \\
\text { deck, } 57.1 \text { up to }\end{array}$ & dec & $79.52 \mathrm{u}$ & poat de & & & \\
\hline
\end{tabular}

To compute the frequency, the lengthwise distribution of the ship parametres, such as weight (including added virtual mass), bending and shear rigidity are necessary. These data were made according to the method shown in the previous report(1) and the results are shown in Table $7 \sim 10$ in the following paper. In the tables, the segment number is counted from stern to bow. Location means the coordinates of after and fore ends of the corresponding segments. These coordinates are expressed as the fraction of ship's length overall and measured from the aft end of ship.

Ships A, B and C are sister ships, the only difference being in the weight distributions. Thus the input data for these three are listed together in Table 7.

Ship D, whose input data are shown in Table 8, is a cargo liner with bridge semi-aft, while ship $A, B$ and $C$ are those with bridge amidships. The difference of rigidity distributions between these two types can be seen clearly from Table 7 and 8 .

Input data of ships $\mathrm{G}$ and $\mathrm{H}$ were shown in the previous report(1).

Ship $\mathrm{E}$ is a tanker whose rigidity distributions are similar to ship $\mathrm{F}$ and her input data are omitted for brevity.

For the cargo liners with bridge amidships or semi-aft, the calculation of bending and shear rigidity has some ambiguity, because the effectiveness of the bridge is not so clear. In this study the calculation of frequencies were made for three cases; i.e. the longitudinal members up to upper deck, bridge deck and boat deck were taken into account for each case respectively (see Table 7 and 8 ).

\section{Comparisons of computed with measuread results. Empirical coefficient.}

The computed frequencies, together with the measured ones, are shown in Table 4 . For convenience the results are also shown in Fig. 1 through Fig. 9 From these figures and table following features can be observed.

(1) In the figures where number of nodes is taken as abscissa and the frequency as ordinate, the 
Table 4 Comparison of computed with measureaa

\begin{tabular}{|c|c|c|c|c|c|c|c|c|c|c|}
\hline \multirow{2}{*}{$\begin{array}{l}\text { Ship } \\
\text { Name }\end{array}$} & \multirow{2}{*}{$\begin{array}{c}\Delta \\
\text { ton }\end{array}$} & \multicolumn{3}{|c|}{2 -node } & \multicolumn{3}{|c|}{ 3-node } & \multicolumn{3}{|c|}{ 4-node } \\
\hline & & measured & computed & $\begin{array}{c}\text { meas } / \\
\text { comp. }\end{array}$ & measured & computed & $\begin{array}{c}\text { meas/ } \\
\text { comp. }\end{array}$ & measured & computed & $\begin{array}{c}\text { meas/ } \\
\text { comp. }\end{array}$ \\
\hline A & 8,100 & ${ }_{107^{c p m}}$ & 107.5 & 0.995 & ${ }_{191^{\text {cpm }}}$ & $\begin{array}{l}\mathbf{c p m} \\
193.5\end{array}$ & 0.987 & ${ }_{-}^{\mathrm{cpm}}$ & $288.3^{\text {cpm }}$ & - \\
\hline B & 11,400 & 100.5 & 99.5 & 1.010 & 182 & 180.3 & 1. 010 & 260 & 265.5 & 0.979 \\
\hline $\mathrm{C}$ & 15,900 & 86 & 87.9 & 0.978 & 158 & 161.7 & 0.977 & - & 253.4 & - \\
\hline & 8,667 & 96 & 93.7 & 1.025 & 178 & 177.5 & 1.003 & 一 & 267.4 & \\
\hline D & 11,356 & 93 & 88.0 & 1.057 & - & 169.9 & - & - & 250.0 & \\
\hline & 43,070 & - & 51.4 & - & 109 & 104.5 & 1.04 & (167) & 161.2 & (1.04) \\
\hline$E$ & 61,392 & - & 48.5 & 一 & (105) & 97.2 & (1.08) & 155 & 150.3 & 1.03 \\
\hline & 29,030 & 54 & 49.5 & 1.09 & (118) & 104.9 & (1.125) & 174 & 165.1 & 1.05 \\
\hline$F$ & 66,289 & 48.8 & 43.7 & 1.12 & 96 & 88.1 & 1.09 & 148 & 137.6 & 1.08 \\
\hline G & 21,652 & 67.5 & 66.4 & 1.02 & - & 133.7 & - & 192 & 209.3 & 0.92 \\
\hline $\mathrm{H}$ & 19,900 & 65 & 63.5 & 1.02 & 130 & 129.9 & 1.00 & 181 & 196.6 & 0.92 \\
\hline I & 32,167 & 56 & 50.9 & 1.10 & 115 & 107.4 & 1.07 & - & 171.4 & - \\
\hline
\end{tabular}

( ) means the value with less accuracy.

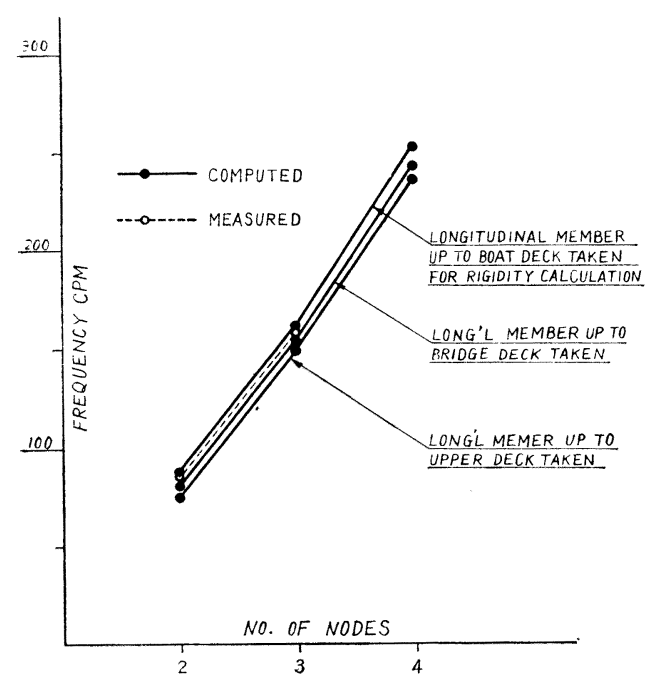

Fig.1 Comparison of computed with measured frequencies of ship A (Cargo Liner).

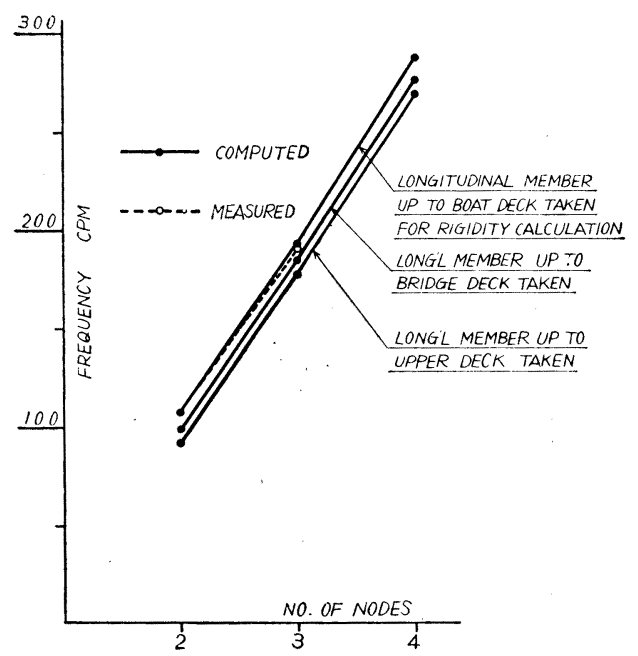

Fig. 3 Comparison of computed with measured frequencies of ship C (Cargo Liner).

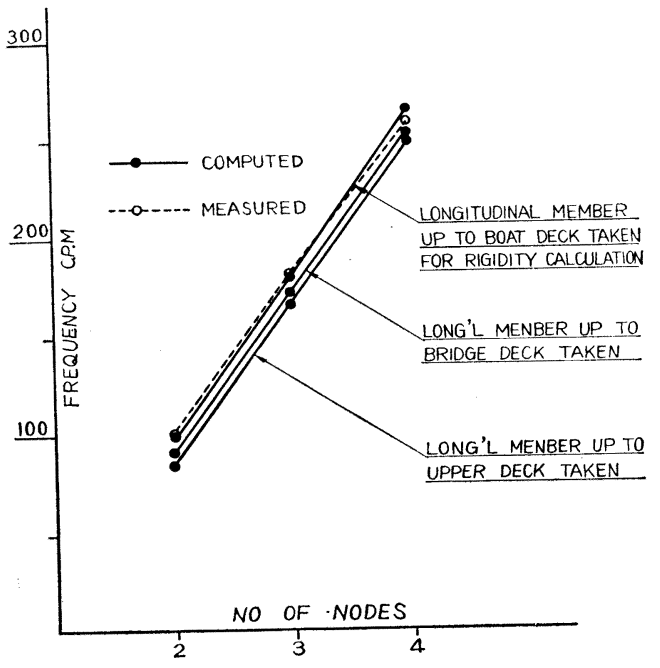

Fig. 2 Comparison of computed with measured frequencies of ship B (Cargo Liner).

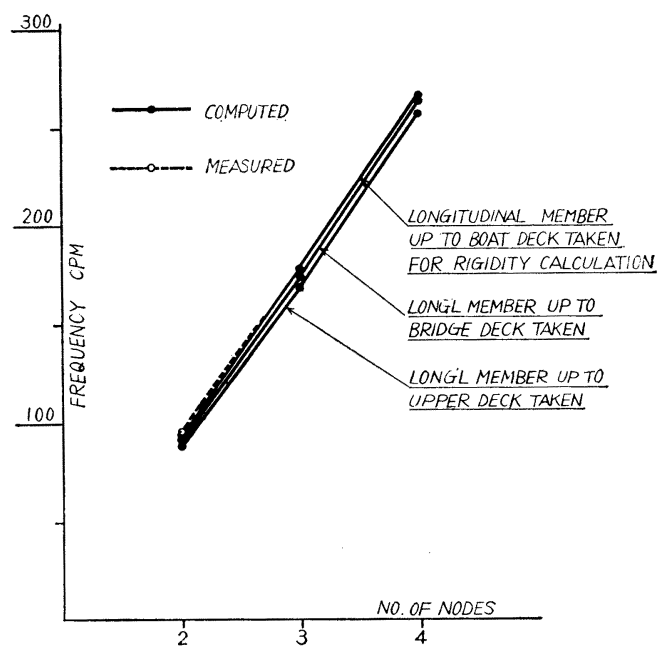

Fig. 4 Comparison of computed with measured frequencies of ship D (Cargo Liner). 
frequencies for ships listed in Table 3

\begin{tabular}{|c|c|c|c|c|c|c|}
\hline \multicolumn{3}{|c|}{ 5-node } & \multicolumn{3}{|c|}{ 6-node } & \multirow[b]{2}{*}{ Remarks } \\
\hline measured & computed & $\begin{array}{l}\text { meas/ } \\
\text { comp. }\end{array}$ & measured & computed & $\begin{array}{c}\text { meas/ } \\
\text { comp. }\end{array}$ & \\
\hline$-^{\mathrm{cpm}}$ & ${ }_{389^{\mathrm{cpm}}}$ & 一 & cpm & $494^{\text {cpm }}$ & 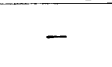 & Longitudinal member up to boat deck taken for \\
\hline & 352 & & & 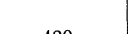 & & rigidity calculation \\
\hline \multirow{3}{*}{-} & 333 & - & & 420 & & \\
\hline & 360 & & & 461 & & Do \\
\hline & 338 & & & 432 & & Lu \\
\hline 218 & 218.8 & 1.00 & & 267.9 & & \\
\hline- & 202.3 & - & $(265)$ & 252.2 & $(1.05)$ & \\
\hline$(230)$ & 216. 8 & $(1.06)$ & - & 276.1 & - & \\
\hline 195 & 188. 2 & 1.04 & - & 233.8 & - & \\
\hline- & 282.3 & - & 312 & & & \\
\hline 222 & 261.6 & 0.85 & & & & \\
\hline 242 & 236.4 & 1.02 & & & & \\
\hline
\end{tabular}

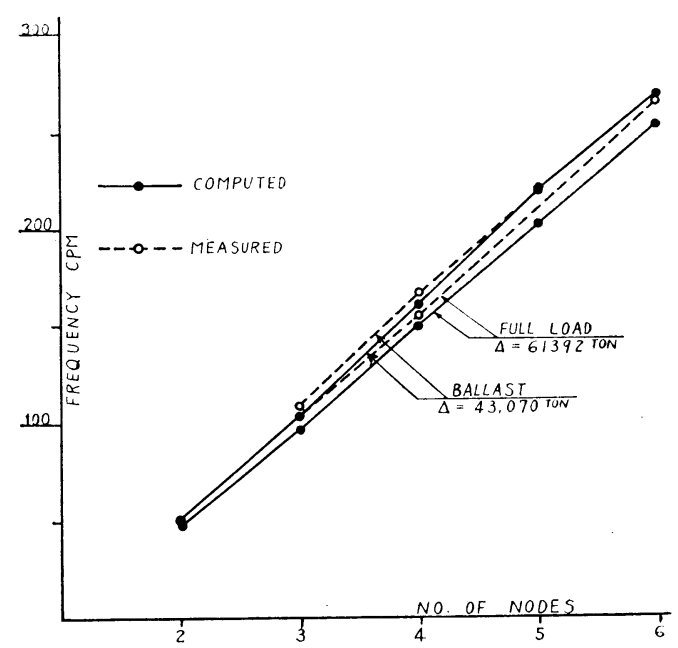

Fig. 5 Comparison of computed with measured frequencies of ship $\mathrm{E}$ (Tanker).

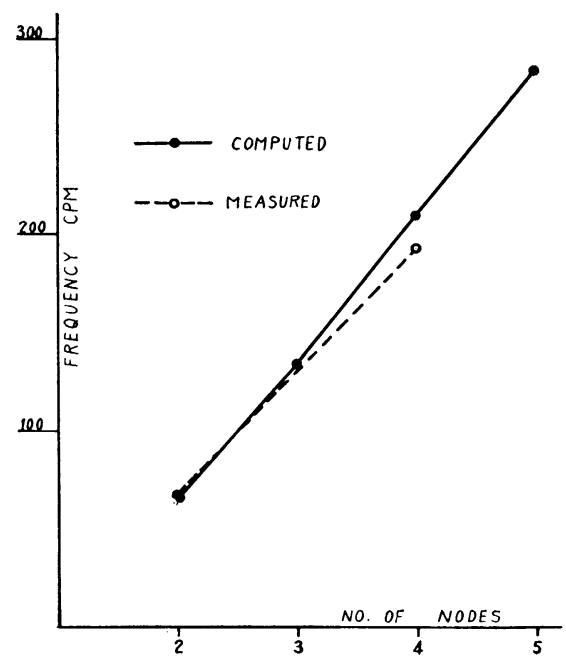

Fig. 7 Comparison of computed with measured frequencies of ship G (Bulk Carrier).

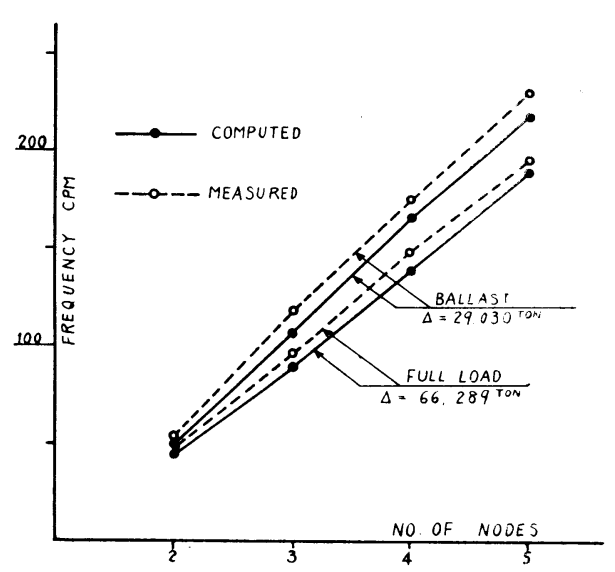

Fig. 6 Comparison of computed with measured freqencies of ship $\mathrm{F}$ (Tanker).

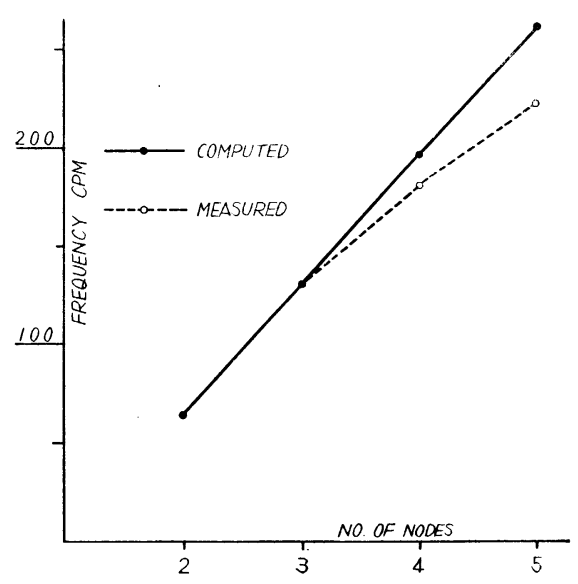

Fig. 8 Comparison of computed with measured frequencies of ship $\mathrm{H}$ (Bulk Carrier). 


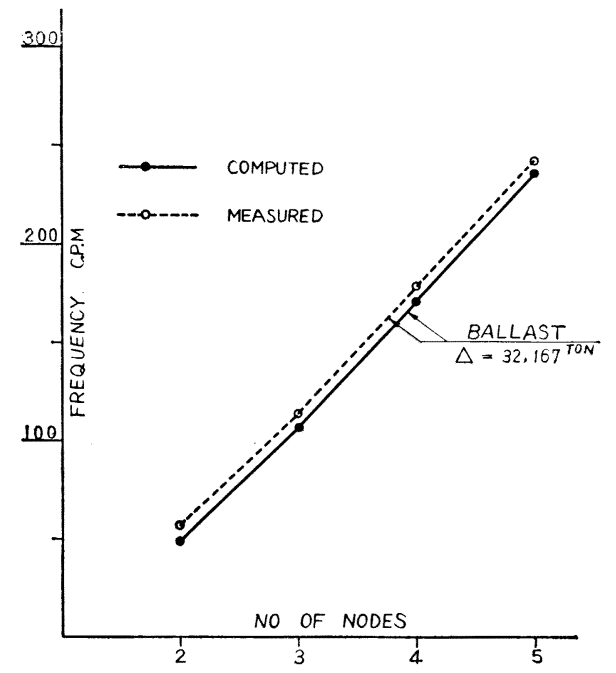

Fig. 9 Comparison of computgd with measured frequencies of ship I (Ore Carrier). computed and the measured values are almost parallel for tanker and ore carrier. In other words, for tanker and ore carrier, the difference between computed and measured frequencies is almost constant in every modes, calculated frequencies being lower than measured ones.

(2) On the contrary, for bulk carriers, the differences between computed and measured frequencies are very small for the lower mode and becomes larger for the higher mode, the computed values being higher than those measured.

(3) In the case of cargo liner, the agreements of computed and measured frequencies are excellent for the lower modes if the longitudinal members up to boat deck are taken into account for the rigidity calculation.

For the higher modes, i.e. above 4 node mode, any definite conclusion can not be drawn for the present because the measured data are lacking. From Fig.2, however, it is supposed that the cargo liner behaves like bulk carrier in the higher mode region, i.e., the actual frequency is lower than the computed value.

In Fig. 10 and 11 are shown the comparison of computed and mesured mode curves. Roughly speaking, the agreements between computed and measured mode curves are reasonable. For more minute inspection the detailer measurement is necessary, using many, say more than 20 measuring points along the ship length.

For the frequency estimation in the design stage, the accuracy of estimation is improved by using
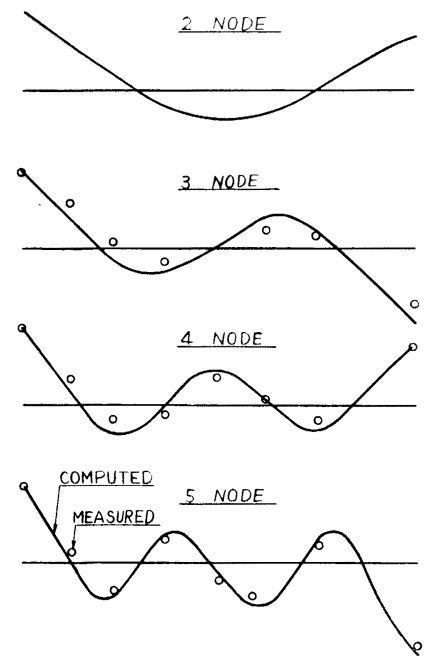

Fig. 10 Comparison of computed with measured mode curves of ship $\mathrm{F}$ for 66, 289 Tons.
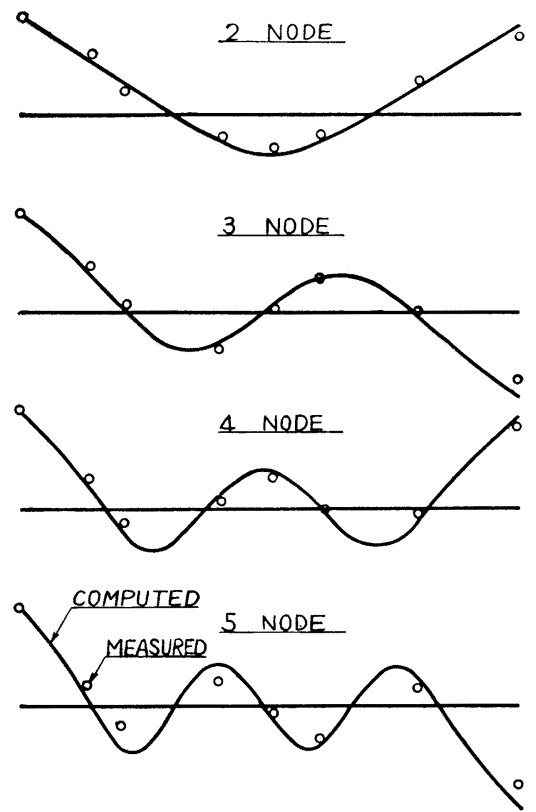

Fig. 11 Comparison of computed with measured mode curves of ship $\mathrm{H}$. 
Table 5 Empirical coefficient for frequency estimation.

\begin{tabular}{|c|c|c|c|c|c|}
\hline Type of Ship & 2 node & 3 node & 4 node & 5 node & Notes \\
\hline $\begin{array}{l}\text { Tanker } \& \\
\text { Ore Carrier }\end{array}$ & 1.10 & 1.07 & 1.06 & 1.02 & \multirow{4}{*}{$\begin{array}{l}\text { In the rigidity calculation the } \\
\text { longitudinal members up to boat } \\
\text { deck are taken into account }\end{array}$} \\
\hline Bulk Carrier & 1.02 & 1.00 & 0.92 & 0.85 & \\
\hline Cargo Liner & 1.02 & 1.01 & 0.98 & - & \\
\hline Destroyer & 1.01 & 1.02 & 1.05 & 1.00 & \\
\hline
\end{tabular}

Empirical Coefficient $=\frac{\text { Measured Frequency }}{\text { Computed Frequency }}$

empirical coefficient. Here the empirical coefficient is deflned as the ratio of measured versus computed frequency. From Table 4 and reference(1) the empirical coefficients as shown in Table 5 have been derived. Judging from the present data, we can estimate the frequency with fair accuracy (say within $3 \%$ of errors) by means of these empirical coefficients.

\section{Discussions on the ship parametres.}

In the previous section the empirical coefficients were derived for frequency estimation by electronic computer. It is believed that this method can serve quite well for the practical use.

Nevertheless, the essential problem regarding the hull vibration has not completely been solved both from the theoretical and practical point of view unless the discrepancies between computed and measured frequencies have vanished.

Since the numerical accuracy of the computer program is sufficient for frequency prediction as mentioned in article 2, the discrepancies between computed and measured frequencies are supposed to have arised from the fact that the actual configuration of hull vibration is different from that assumed in the theoretical computation.

The difference is supposed to be classified into the following items.

\section{Inaccuracy in the prediction of ship parametres}

In preparing the input data for computation, ship parametres such as added virtual mass, rotational inertia, bending and shear rigidity has been derived by some existing theories. If there are some errors in these derivations, the results may be inaccurate.

\section{Roughness in the input data preparation}

Even if the above mentioned ship parametres have been derived reasonably, the results of frequency computation again become inaccurate if the numerical roughness of the input data is considerable. As shown in Tables $7 \sim 10$, ships' length overall has been divided into $40 \sim 50$ segments in the frequency computation, but this does not mean that rigidity, weight etc. have been predicted exactly for each segments. As shown in the previous report the hull weight distribution has been calculated by means of the modified Biles method. Bending and shear rigidity has been calculated at 10 15 sections along the length and the distribution curve has been drawn smoothly through these points. Such a roughness in the input data preparation may be a part of the cause of discrepancies.

Deviation of ship structure from the beam theory.

Two items above-mentioned are within the category of so-called beam theory. On the contrary, in some cases the ship structure is considered to deviate from the beam theory. Recently the attention has been often paid to such a phenomenon.

Within this category is the coupling of the local vibration.

If the local vibration is coupled with the main hull, it is expected to affect the natural frequency to some extent.

Of three items above-mentioned, the last is a very interesting phenomenon and will be a central 
Table 6 Effect of Rotational Inertia on the Frequencies of Ship F.

\begin{tabular}{|c|c|c|c|c|c|}
\hline \multirow{2}{*}{$\begin{array}{l}\text { No. of } \\
\text { nodes }\end{array}$} & \multirow{2}{*}{$\begin{array}{c}\text { Rotational inertia } \\
\text { neglected }\end{array}$} & \multicolumn{4}{|c|}{ Rotational inertia taken into account } \\
\hline & & \multicolumn{2}{|c|}{$\beta=0.00246^{* *}$} & \multicolumn{2}{|c|}{$\beta=0.0246^{* *}$} \\
\hline 2 & $43.7 \quad \mathrm{cpm}$ & 42.8 & cpm & 38.3 & $\mathrm{cpm}$ \\
\hline 3 & 88.1 & 86.9 & & 76.9 & $19.0^{*}$ \\
\hline 4 & 137.6 & 136. 2 & & 122.3 & \\
\hline 5 & 188.2 & 186.4 & & 166. 2 & \\
\hline 6 & 233.8 & 231.6 & & 196.8 & $223.3^{*}$ \\
\hline 7 & & 273.9 & & 242.1 & \\
\hline 8 & & 312.7 & & 281.9 & $332.6^{*}$ \\
\hline 9 & & 356.8 & & 323.2 & \\
\hline 10 & & 398.4 & & 366.9 & \\
\hline 11 & & 443.6 & & 403.9 & \\
\hline 12 & & 486.8 & & 450.6 & \\
\hline 13 & & 526.5 & $555.0^{*}$ & 500.2 & \\
\hline 14 & & 569.1 & $594.9 *$ & 546.2 & $583.1^{*}$ \\
\hline 15 & & 624.7 & & & \\
\hline
\end{tabular}

* Coupling caused by the effect of rotational inertia

** Actual $\beta$ of ship $\mathrm{F}$ is about 0.00029

Table 7 Input data of ship A, B and C

\begin{tabular}{|c|c|c|c|c|c|c|c|c|c|c|}
\hline \multirow{3}{*}{$\begin{array}{c}\text { Segment } \\
\text { No. }\end{array}$} & \multirow{2}{*}{ Location } & \multicolumn{3}{|c|}{ Bending rigidity up to } & \multicolumn{3}{|c|}{ Shear rigidity up to } & \multicolumn{3}{|c|}{ Weight distribution } \\
\hline & & boat deck & \begin{tabular}{|c|} 
bridge \\
deck
\end{tabular} & $\begin{array}{c}\text { upper } \\
\text { deck }\end{array}$ & boat deck & \begin{tabular}{|c|} 
bridge \\
deck \\
\end{tabular} & $\begin{array}{c}\text { upper } \\
\text { deck }\end{array}$ & $\operatorname{ship} A$ & $\operatorname{ship} B$ & ship C \\
\hline & $\times$ ship length & \multicolumn{3}{|c|}{$\times 10^{8}$ ton $-\mathrm{m}^{2}$} & \multicolumn{3}{|c|}{$\times 10^{6}$ ton } & \multicolumn{3}{|c|}{$\operatorname{ton} / \mathrm{m}$} \\
\hline 1 & $0.000 \sim 0.026$ & 0.4 & 0.4 & 0.4 & 0.3 & 0.3 & 0.3 & 10 & 10 & 10 \\
\hline 2 & $0.026 \sim 0.051$ & 0.6 & 0.6 & 0.6 & 1.0 & 1.0 & 1.0 & 30 & 30 & 30 \\
\hline 3 & $0.051 \sim 0.077$ & 2.4 & 2.4 & 2.4 & 2.1 & 2.1 & 2.1 & 48 & 52 & 36 \\
\hline 4 & $0.077 \sim 0.103$ & 3.5 & 3.5 & 3.5 & 2.4 & 2.4 & 2.4 & 36 & 40 & 82 \\
\hline 5 & $0.103 \sim 0.128$ & 3.7 & 3.7 & 3.7 & 2.4 & 2.4 & 2.4 & 40 & 50 & 124 \\
\hline 6 & $0.128 \sim 0.154$ & 3.8 & 3.8 & 3.8 & 2.3 & 2.3 & 2.3 & 62 & 70 & 160 \\
\hline 7 & $0.154 \sim 0.180$ & 4.1 & 4.1 & 4.1 & 2.3 & 2.3 & 2.3 & 70 & 94 & 166 \\
\hline 8 & $0.180 \sim 0.205$ & 4.8 & 4.8 & 4.8 & 2.3 & 2.3 & 2.3 & 90 & 136 & 176 \\
\hline 9 & $0.205 \sim 0.231$ & 5.7 & 5.7 & 5.7 & 2.6 & 2.6 & 2.6 & 100 & 160 & 200 \\
\hline 10 & $0.231 \sim 0.256$ & 6.5 & 6.5 & 6.5 & 2.6 & 2.6 & 2.6 & 138 & 184 & 220 \\
\hline 11 & $0.256 \sim 0.282$ & 7.8 & 7.4 & 7.2 & 2.7 & 2.6 & 2.6 & 148 & 198 & 240 \\
\hline 12 & $0.282 \sim 0.308$ & 9.3 & 8.3 & 7.7 & 2.8 & 2.8 & 2.7 & 166 & 228 & 264 \\
\hline 13 & $0.308 \sim 0.333$ & 10.7 & 9.1 & 8.2 & 3.0 & 2.8 & 2.7 & 208. & 270 & 286 \\
\hline 14 & $0.333 \sim 0.359$ & 12.0 & 10.0 & 8.8 & 3.1 & 2.8 & 2.7 & 218 & 256 & 296 \\
\hline 15 & $0.359 \sim 0.385$ & 13.5 & 10.8 & 9.4 & 3. 2 & 2.8 & 2.7 & 225 & 286 & 306 \\
\hline 16 & $0.385 \sim 0.411$ & 14.9 & 11.7 & 9.9 & 3.3 & 2.9 & 2.7 & 236 & 298 & 318 \\
\hline 17 & $0.411 \sim 0.436$ & 16.1 & 12.3 & 10.2 & 3.4 & 2.9 & 2.7 & 276 & 254 & 274 \\
\hline 18 & $0.436 \sim 0.462$ & 16.4 & 12.2 & 9.8 & 3.4 & 2.9 & 2.7 & 280 & 258 & 276 \\
\hline 19 & $0.462 \sim 0.487$ & 16.4 & 12.1 & 9.3 & 3.3 & 2.9 & 2.6 & 280 & 258 & 276 \\
\hline 20 & $0.487 \sim 0.513$ & 16.7 & 12.0 & 8.9 & 3.3 & 2.9 & 2.5 & 280 & 260 & 276 \\
\hline 21 & $0.513 \sim 0.538$ & 15. 6 & 11.5 & 8.5 & 3.4 & 2.9 & 2.6 & 288 & 282 & 274 \\
\hline 22 & $0.538 \sim 0.564$ & 14.0 & 10.7 & 3.0 & 3.5 & 3.0 & 2.7 & 240 & 244 & 344 \\
\hline 23 & $0.564 \sim 0.590$ & 12.5 & 9.8 & 7.7 & 3.6 & 3.0 & 2.8 & 232 & 222 & 322 \\
\hline 24 & $0.590 \sim 0.615$ & 11.3 & 9.4 & 7.7 & 3.4 & 3.0 & 2.8 & 190 & 206 & 316 \\
\hline 25 & $0.615 \sim 0.641$ & 10.1 & 8.8 & 7.7 & 3.25 & 3.0 & 2.8 & 182 & 198 & 308 \\
\hline 26 & $0.641 \sim 0.667$ & 8.9 & 8.3 & 7.7 & 3.1 & 3.0 & 2.9 & 170 & 186 & 280 \\
\hline 27 & $0.667 \sim 0.692$ & 7.8 & 7.8 & 7.7 & 2.9 & 3.0 & 2.9 & 160 & 226 & 222 \\
\hline 28 & $0.692 \sim 0.718$ & 7.4 & 7.4 & 7.4 & 3.0 & 3.0 & 3.0 & 142 & 248 & 102 \\
\hline 29 & $0.718 \sim 0.744$ & 7.1 & 7.1 & 7.1 & 3.0 & 3.0 & 3.0 & 124 & 226 & 182 \\
\hline 30 & $0.744 \sim 0.769$ & 6.7 & 6.7 & 6.7 & 3.0 & 3.0 & 3.0 & 98 & 196 & 154 \\
\hline 31 & $0.769 \sim 0.795$ & 6.4 & 6.4 & 6.4 & 3.0 & 3.0 & 3.0 & 88 & 176 & 154 \\
\hline 32 & $0.795 \sim 0.821$ & 6.0 & 6.0 & 6.0 & 3.0 & 3.0 & 3.0 & 66 & 112 & 146 \\
\hline 33 & $0.821 \sim 0.846$ & 5.7 & 5.7 & 5.7 & 3.0 & 3.0 & 3.0 & 46 & 64 & 112 \\
\hline 34 & $0.846 \sim 0.872$ & 5.4 & 5.4 & 5.4 & 3.1 & 3.1 & 3.1 & 34 & 52 & 80 \\
\hline 35 & $0.872 \sim 0.898$ & 5.1 & 5.1 & 5.1 & 3.1 & 3.1 & 3.1 & 26 & 38 & 66 \\
\hline 36 & $0.898 \sim 0.923$ & 4.7 & 4.7 & 4.7 & 3.1 & 3.1 & 3.1 & 34 & 36 & 42 \\
\hline 37 & $0.923 \sim 0.949$ & 2.8 & 2.8 & 2.8 & 2.4 & 2.4 & 2.4 & 34 & 30 & 26 \\
\hline 38 & $0.949 \sim 0.975$ & 1.1 & 1.1 & 1.1 & 1.6 & 1.6 & 1.6 & 18 & 18 & 18 \\
\hline 39 & $0.975 \sim 1.000$ & 0.3 & 0.3 & 0.3 & 0.7 & 0.7 & 0.7 & 6 & 6 & 6 \\
\hline
\end{tabular}




\begin{tabular}{|c|c|c|c|c|c|c|c|c|c|c|}
\hline 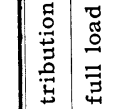 & 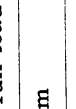 & 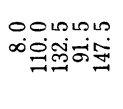 & 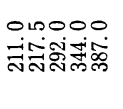 & 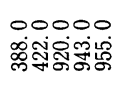 & 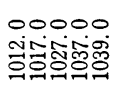 & 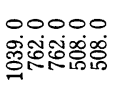 & 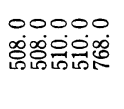 & 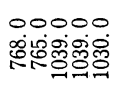 & 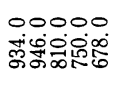 & 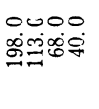 \\
\hline 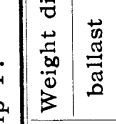 & & 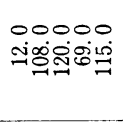 & 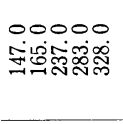 & 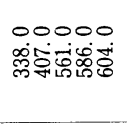 & 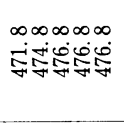 & 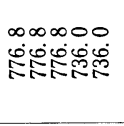 & 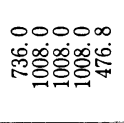 & 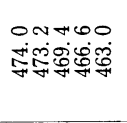 & 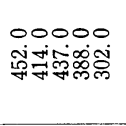 & 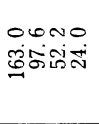 \\
\hline 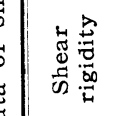 & 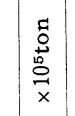 & 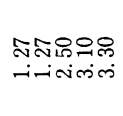 & $\begin{array}{l}\text { டீ88: } \\
\text { minnmit }\end{array}$ & 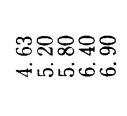 & 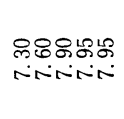 & ஓஜஃஃ & 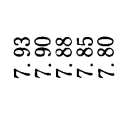 & $\begin{array}{l}\text { ㅁosiog } \\
\text { Nivinis }\end{array}$ & $\begin{array}{l}\text { 8ని요 } \\
\text { Nivitim }\end{array}$ & 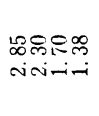 \\
\hline 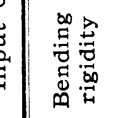 & 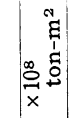 & 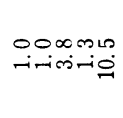 & 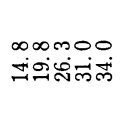 & 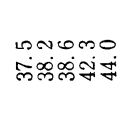 & 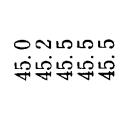 & 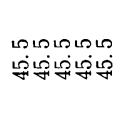 & 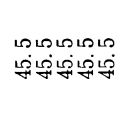 & 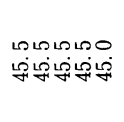 & 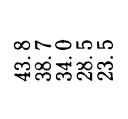 & $\begin{array}{l}0000 \\
\therefore 0+-1\end{array}$ \\
\hline 苛 & 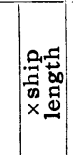 & 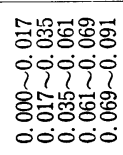 & 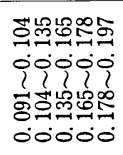 & 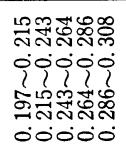 & 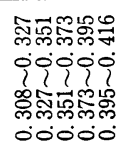 & 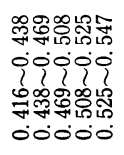 & 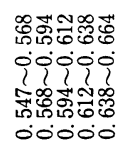 & 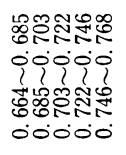 & 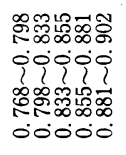 & 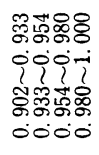 \\
\hline 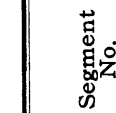 & & ーNMオ゙ & anoso & ㅋフコニ゙ & 누요 & 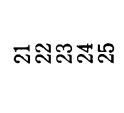 & బిస్నిన్లి & అల్లల్లుడ్ల & 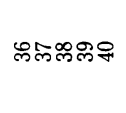 & テテฺダ \\
\hline
\end{tabular}

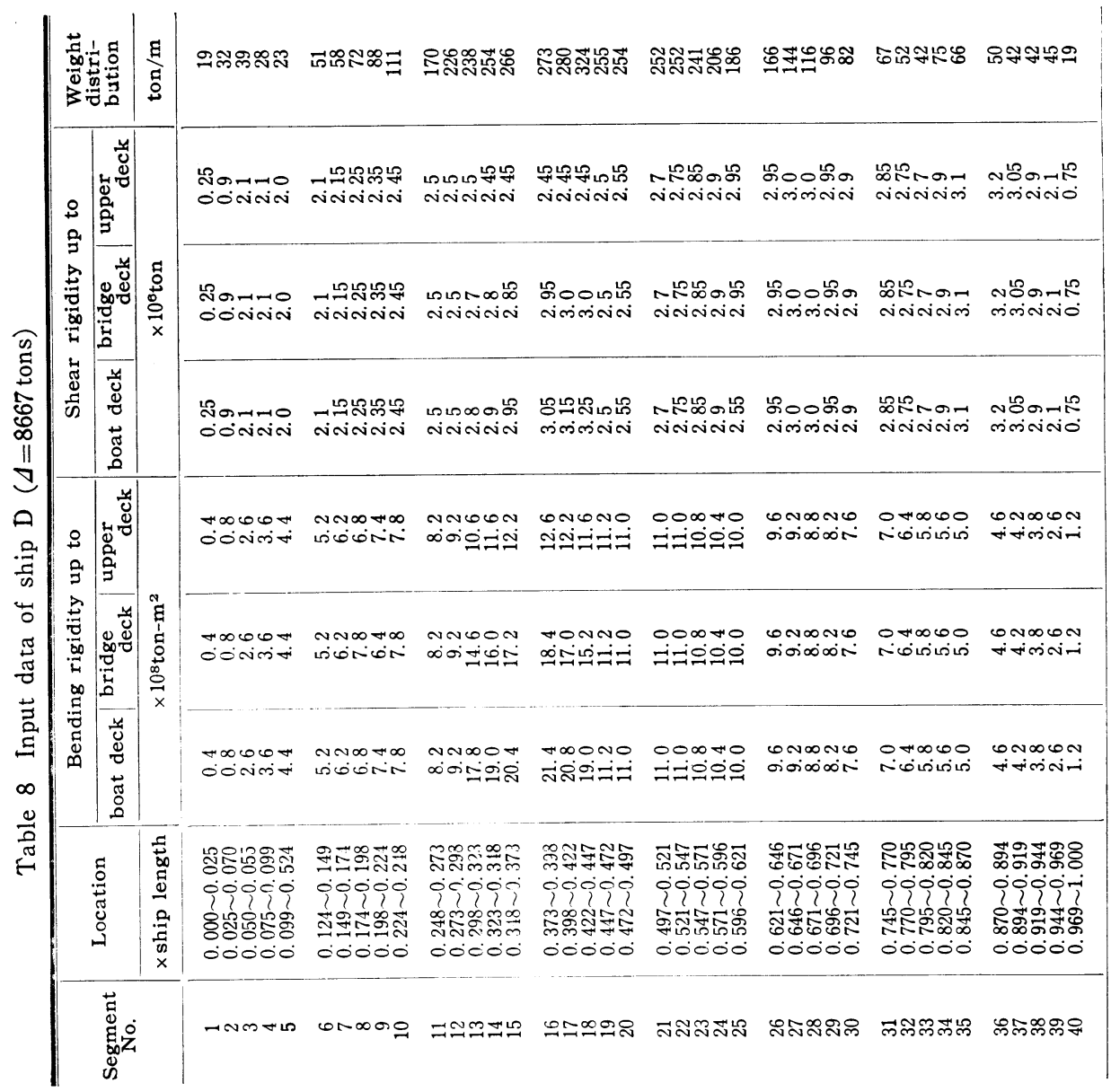


Table 10 Input data of ship I

\begin{tabular}{|c|c|c|c|c|c|c|c|c|c|}
\hline $\begin{array}{l}\text { Segment } \\
\text { No. }\end{array}$ & Location & $\begin{array}{l}\text { Bending } \\
\text { rigidity }\end{array}$ & $\begin{array}{l}\text { Shear } \\
\text { rigidity }\end{array}$ & $\begin{array}{l}\text { Weight } \\
\text { distri- } \\
\text { bution }\end{array}$ & $\begin{array}{c}\text { Segment } \\
\text { No. }\end{array}$ & Location & $\begin{array}{l}\text { Bending } \\
\text { rigidity }\end{array}$ & $\begin{array}{l}\text { Shear } \\
\text { rigidity }\end{array}$ & $\begin{array}{l}\text { Weight } \\
\text { distri- } \\
\text { bution }\end{array}$ \\
\hline & $\times$ ship length & $\begin{array}{l}\times 10^{8} \\
\text { ton } / \mathrm{m}^{2}\end{array}$ & $\times 10^{8}$ ton & $\operatorname{ton} / \mathrm{m}$ & & $\times$ ship length & $\begin{array}{l}\times 10^{8} \\
\text { ton } / \mathrm{m}^{2}\end{array}$ & $\times 10^{6}$ ton & $\operatorname{ton} / \mathrm{m}$ \\
\hline 1 & $0.000 \sim 0.022$ & 3.15 & 0.5 & 32 & 24 & $0.508 \sim 0.530$ & 41.16 & 8.2 & 681 \\
\hline 2 & $0.022 \sim 0.044$ & 3.78 & 0.9 & 64 & 25 & $0.530 \sim 0.552$ & 40.74 & 8.1 & 423 \\
\hline 3 & $0.044 \sim 0.066$ & 7.14 & 1.5 & 73 & 26 & $0.552 \sim 0.574$ & 40.32 & 8.1 & 423 \\
\hline 4 & $0.066 \sim 0.088$ & 11.34 & 2.1 & 155 & 27 & $0.574 \sim 0.596$ & 39.9 & 8.1 & 423 \\
\hline 5 & $0.088 \sim 0.110$ & 15. 12 & 2.7 & 135 & 28 & $0.596 \sim 0.618$ & 39.27 & 8.1 & 681 \\
\hline 6 & $0.110 \sim 0.132$ & 19.32 & 3.3 & 147 & 29 & $0.618 \sim 0.640$ & 38.85 & 8.1 & 681 \\
\hline 7 & $0.132 \sim 0.155$ & 22.89 & 3.9 & 179 & 30 & $0.640 \sim 0.662$ & 38.43 & 7.9 & 681 \\
\hline 8 & $0.155 \sim 0.177$ & 26.04 & 5.0 & 221 & 31 & $0.662 \sim 0.684$ & 38.01 & 7.9 & 680 \\
\hline 9 & $0.177 \sim 0.199$ & 29.4 & 6.2 & 279 & 32 & $0.684 \sim 0.706$ & 37.59 & 7.9 & 680 \\
\hline 10 & $0.199 \sim 0.221$ & 31.29 & 7.2 & 286 & 33 & $0.706 \sim 0.728$ & 36.96 & 7.9 & 534 \\
\hline 11 & $0.221 \sim 0.243$ & 32.76 & 7.8 & 334 & 34 & $0.728 \sim 0.751$ & 36.54 & 7.9 & 421 \\
\hline 12 & $0.243 \sim 0.265$ & 34.86 & 7.9 & 379 & 35 & $0.751 \sim 0.773$ & 36.12 & 7.8 & 421 \\
\hline 13 & $0.265 \sim 0.287$ & 36.54 & 8.0 & 525 & 36 & $0.773 \sim 0.795$ & 35.7 & 7.7 & 585 \\
\hline 14 & $0.287 \sim 0.309$ & 38.22 & 8.1 & 545 & 37 & $0.795 \sim 0.817$ & 34.86 & 7.5 & 620 \\
\hline 15 & $0.309 \sim 0.331$ & 38.64 & 8.1 & 552 & 38 & $0.817 \sim 0.839$ & 30.24 & 7.3 & 595 \\
\hline 16 & $0.331 \sim 0.353$ & $39.0 \dot{6}$ & 8.1 & 676 & 39 & $0.839 \sim 0.861$ & 26.46 & 7.2 & 365 \\
\hline 17 & $0.353 \sim 0.375$ & 39.48 & 8.1 & 676 & 40 & $0.861 \sim 0.883$ & 22.26 & 6.9 & 277 \\
\hline 18 & $0.375 \sim 0.397$ & 39.69 & 8.1 & 681 & 41 & $0.883 \sim 0.905$ & 18.48 & 4.8 & 217 \\
\hline 19 & $0.397 \sim 0.419$ & 40.11 & 8.2 & 425 & 42 & $0.905 \sim 0.927$ & 13.86 & 3.1 & 152 \\
\hline 20 & $0.419 \sim 0.442$ & 40.32 & 8.2 & 425 & 43 & $0.927 \sim 0.949$ & 9.66 & 2.0 & 95 \\
\hline 21 & $0.442 \sim 0.464$ & 40.74 & 8.2 & 425 & 44 & $0.949 \sim 0.971$ & 5.04 & 0.9 & 60 \\
\hline 22 & $0.464 \sim 0.486$ & 41.37 & 8.2 & 681 & 45 & $0.971 \sim 1.000$ & 4. 20 & 1.0 & 26 \\
\hline 23 & $0.486 \sim 0.508$ & 41.37 & 8.2 & 681 & & & & & \\
\hline
\end{tabular}

topic in the future. Recently Prof. Yamakoshi et al ${ }^{(8)}$ have published a new theory on the coupled vibration of hull and bottom structure, which is a first step towards the new topic. But the authors leave this subject in the future and it is not treated in this report.

The second item may deserve attention from the practical point of view. In fact the authors have an experience that, in the calculation of the same ship, the computed frequency varies by about $1 \sim$ $3 \%$ according to the difference in the data preparation. But the authors have an impression that, although this item can not be neglected, of primary importance is the first item. Hence the first item will be treated exclusively hereafter.

A. Virtual Added Mass.

As mentioned in the previous report(1), the Landweber's two parametre family ${ }^{(9)}$ with Lewis' threedimensional factor(10) was used for the estimation of virtual mass for 2-noded vibration. For the higher mode vibrations the virtual mass was taken the same as for 2-noded. For the purpose of examining the validity of the above-mentioned estimation, two aspects must be considered;i.e.

(1) the two-dimensional calculation of added mass, and (2) three-dimesional correction factor for each mode of vibration.

For the two-dimensional calculation (strip theory), various methods have been proposed, such as, Lewis Forms ${ }^{(10)}$, prohaska Forms ${ }^{(11)}$, Landweber's two-parametre(9) and three-parametre family ${ }^{(12)}$. The main difference among these studies is the difference of the image functions used in the conformal transformation.

Landweber's two-parametre family used in this report has a transform function in the following forms,

$$
z=\zeta+\frac{a_{1}}{\zeta}+\frac{a_{2}}{\zeta^{3}}
$$

where $\quad z$ : variable in the plane of ship section

$\zeta$ : variable in the plane of unit circle.

$a_{1}, a_{2}:$ arbitrary corstant. 
Since eq (1) has two arbitrary constants, we can express various forms of sections by properly arranging the constants.

In Landwebers method. $a_{1}$ and $a_{2}$ are determined such as $\lambda$ and $\sigma$ of the transformed section are equal to those of the actual ship section, where

and

$$
\left.\begin{array}{l}
\lambda: \text { breadth to draft ratio } \\
\sigma: \text { section area ratio. }
\end{array}\right\} \text { (see Fig. 12) }
$$

In this method for two sections with different forms but with same $\lambda$ and $\sigma$, the calculated added mass has the same value. Further the transformed forms by eq. (1) are considerably different from the actual forms if $\lambda$ and $\sigma$ take excessive values. Thus Landweber defined the domain for $\lambda$ and $\sigma$ in which transform (1) is realistic (see Fig. 12). Landweber's three-parametre family is an extention. of (1) and takes the form ;

$$
z=\zeta+\frac{a_{1}}{\zeta}+\frac{a_{1}}{\zeta^{3}}+\frac{a_{3}}{\zeta^{5}}
$$

Here an additional constant appears, by which the transform becomes more realistic and the available domain can by extended (see Fig.12).

It is interesting, from the practical point of view, how the $\lambda$ and $\sigma$ of actual ship section distribute. In Fig. 12 are shown the value of $\lambda$ and $\sigma$ for two types of ships. Ship $F$ has been described in this. report. Model A has lines of fine passenger ships. It is seen in Fig. 12 that the value of $\lambda$ and $\sigma$ sometimes go out of the available domain for full ships. For sections whose $\lambda$ and $\sigma$ exceeds the limit. shapes of acual and transformed sections are compared in Fig.13. From the visual impression the discrepancy is not so large. This encourages us to use the two-parametre family.

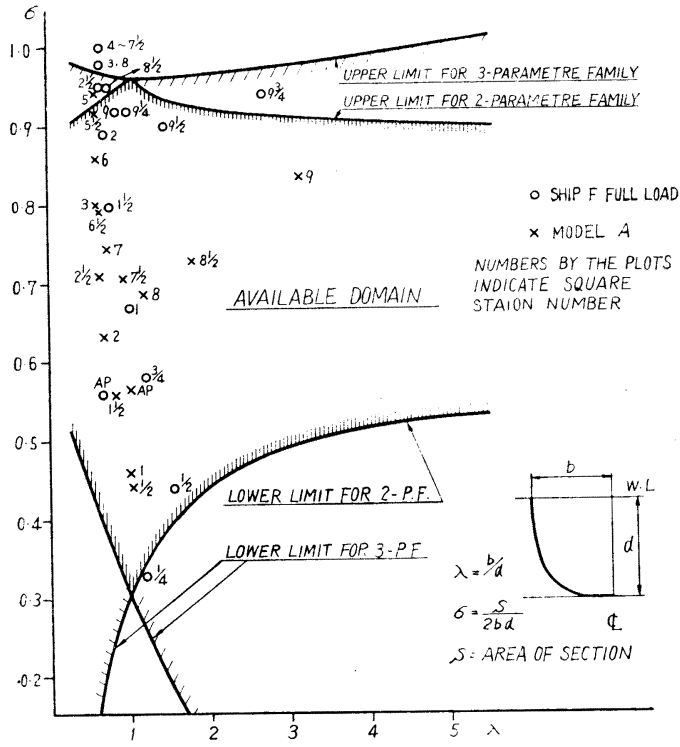

Fig. 12 Domain for $\lambda$ and $\sigma$ within which transforms (1) and (2) are available.
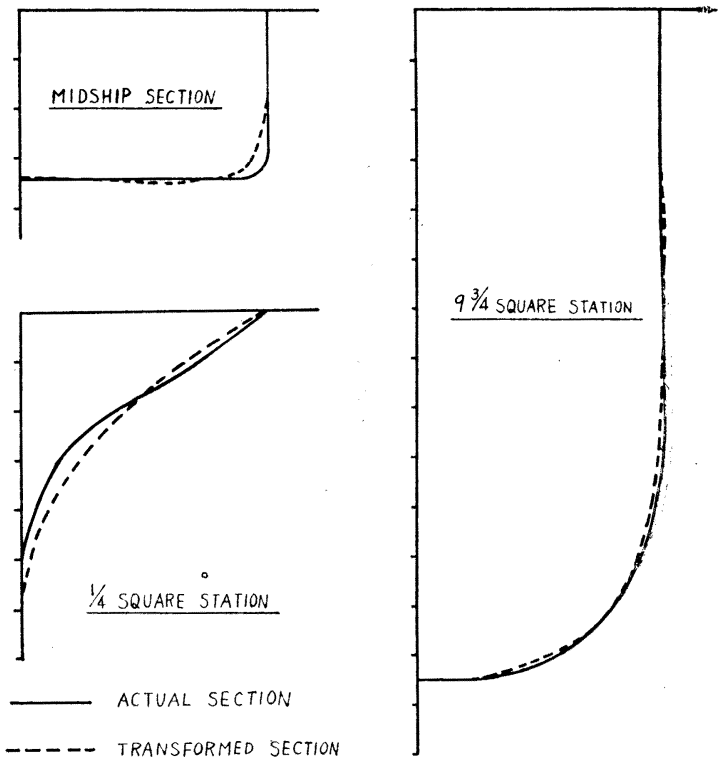

Fig. 13 Comparison of transformed with actua? sections whose $\lambda$ and $\sigma$ deviate the limits of Fig. 12.

Regarding the three-dimensional correction factor, investigations have been made by Taylor ${ }^{(13)}$, Lewis'(10), Prof. Kumai(13)(14), Burrill et al(15) and Dutton et al(7).

In spite of these studies, the three-dimensional correction factor is not considered to have been clarified completely, especially for the higher modes. Thus a simple preliminary test has been carried 
out in our laboratory.

Vibration experiments were made for model ships in air and on water, and the frequency ratios were derived. On the other hand, the frequency calculation were made with and without added virtual mass, and the frequency ratios were compared with experiments. Two types of model ships were used, model $\mathrm{A}$ and model B. Their particulars are shown in Table 11.

Table 11 List of Particulars of Model Ships.

\begin{tabular}{c|c|c}
\hline & Model A & Model B \\
\hline Type & $\begin{array}{c}\text { with lines of passenger boat } \\
\text { (without Saperstructure) }\end{array}$ & $\begin{array}{c}\text { wall sided vessel } \\
\text { (without Superstructure) } \\
\text { Material }\end{array}$ \\
$\begin{array}{c}\text { Plastics } \\
\text { P } \times \text { B } \times \mathrm{D}\end{array}$ & $280 \mathrm{~cm} \times 38.6 \mathrm{~cm} \times 28.6 \mathrm{~cm}$ & $280 \mathrm{~cm} \times 38.6 \mathrm{~cm} 28.6 \mathrm{~cm}$ \\
Draft & $11.5 \mathrm{~cm}$ & $11.5 \mathrm{~cm}$ \\
Displacement & $72 \mathrm{~kg}$ & $115.6 \mathrm{~kg}$ \\
\hline
\end{tabular}

Added mass calculations were made according to the method described above. Comparison of measured with compnted frequencics is shown in Table 12 .

Table 12 Ratio of Natural Frequencies on water to those in air.

\begin{tabular}{c|l|c|c|c}
\hline Model & & 2-Node & 3-Node & 4-Node \\
\hline \multirow{3}{*}{ A } & Experimental & 0.798 & 0.773 & $\begin{array}{l}0.73 \mathrm{~s}^{*} \\
0.790^{*} \\
0.743\end{array}$ \\
& Computed & 0.815 & 0.758 & 0.665 \\
B & Experimental & 0.648 & 0.648 & 0.679 \\
& Computed & 0.672 & 0.670 & \\
\hline
\end{tabular}

* 2 kinds of 4 node vibration appeared in the experiment on water. die to the coupling with local vibraton.

From Table 12, the following conclusions are drawn.

(1) Landweber's 2-parametre family with Lewis' three dimensional correction gives practically good results for 2-noded vibration.

(2) As Prof. Kumai has stated(14) the assumption that the lengthwise distribution of three-dimensional correction factor is uniform gives fairly good results.

(3) In the case of wall-sided vessel, the 3-dimensinal correction is practically constant in every mode. In the fine ship it decreases gradually in the higher mode. To clarify the details of the tendency, the detailed experiment is necessary. For practical use, the virtual mass can be taken constant in any mode.

B. Rotational Inertia.

In the previous report(1) the authors investigated the effect of rotational inertia on the frequency of destroyers and concluded that the effect of rotational inertia can be neglected.

The effect of rotational inertia is determined by the value of $\beta$, where

$$
\beta=\frac{I_{m}}{w l^{2}}
$$

$I_{m}:$ rotational inertia,

$w:$ weight per unit length

and $\quad l$ : length.

In the case of the alove-mentioned destroyer and ship $F$ in full load, $\beta=0.00025$ and $\beta=0.00029$ 
respectively at midship and are practically of no effect.

Here the hypothetical cases in which $\beta=0.0025$ (10 times the usual value) and $\beta=0.025$ (100 times the actual value) were treated for ship $F$ to examine the effect of rotational inertia. The results are shown in Table 6. From this table it is concluded that rotational inertia effect is small at least under $6 \sim 7$ node mode. Also from this table the appearance of 2 nd spectrum is understood. As an example of mode curve of 2 nd spectrum, Fig 14 is presented.

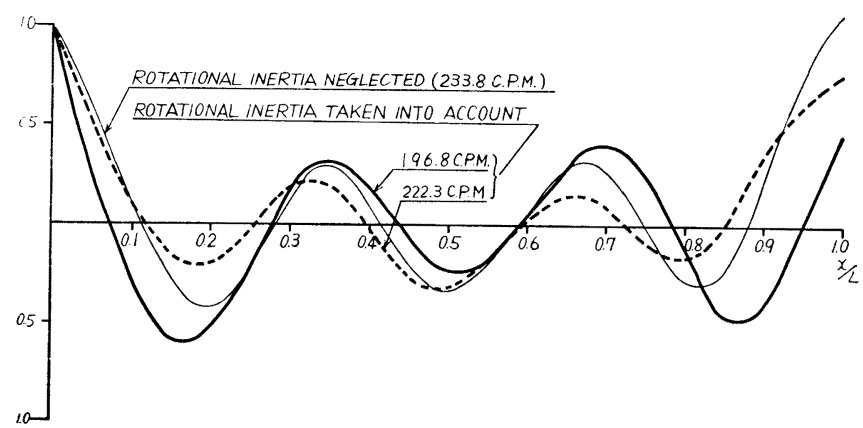

Fig. 14 An example of mode curves for extra modes shown in table 5 (rotational inertia taken about 100 times the actual value).

\section{Effective Breadth}

In the article 4 the authors have indicated that the frequency tendencies of tankers and ore-carrier are completely different from those of bulk carriers and perhaps cargo liners. This difference depending on the ship type can not be attributed to the virtual mass nor rotational inertia, because the former changes very little according to the ship type and the latter has little effect on the frequency, as has been shown in the preceding discussions.

The most probable cause is the effect of the effective breadth of deck and bottom.

Since tanker and ore-carrier have longitudinal bulkheads, the deck plating between side shell and the bulkhead suffers tension and compression on both sides in the case of bending deflection. Hence the bending of the deck plate in its own plane is small and the effective breadth is practically $100 \%$. On the contrary bulk carrier and cargo liner has no longitudinal bulkhead and the deck plating suffers

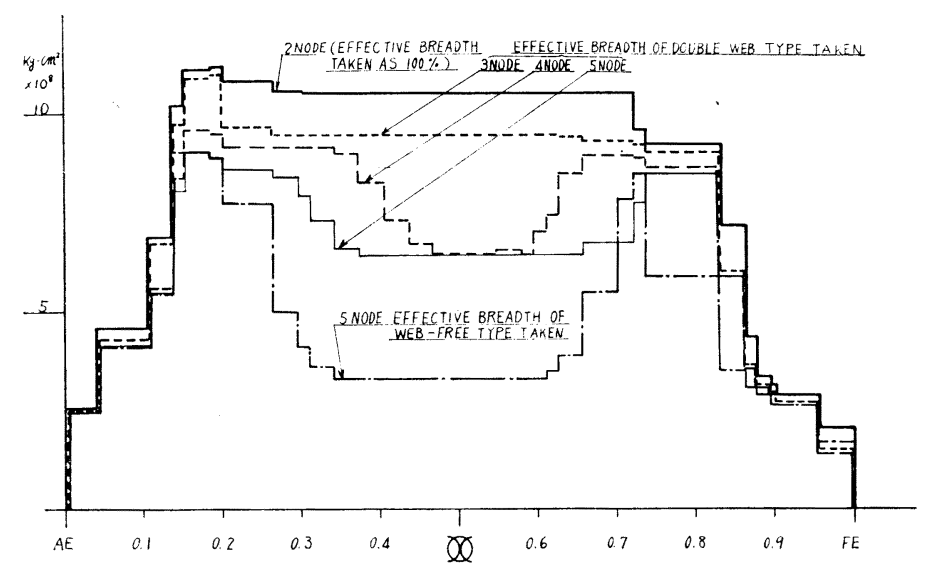

Fig. 15 Change of bending regidity of model $B$ when the effective breadth of deck and bottom is considered according to Schade's theory. 
tension and compression on one side only, the bending of the deck plating in its own plane arising easily. Thus the effective breadth is lessened considerably. According to H. A. Schade(16)(17) the former is the effective breadth of double web type and the latter of web free type and both types differ to a great exent.

For the preliminary check of this problem, the calculations were carried out for model B mentioned above, and the results were compared with experiment.

The Bending rigidity distributions with and without effective breadth concept are shown in Fig. 15. It is seen from this figure that the effect of effective breadth on the bending rigidity is considerable especially for the higher mode and in the case of web-free type.

Table 13 Effect of effective breadth on the frequency of model B

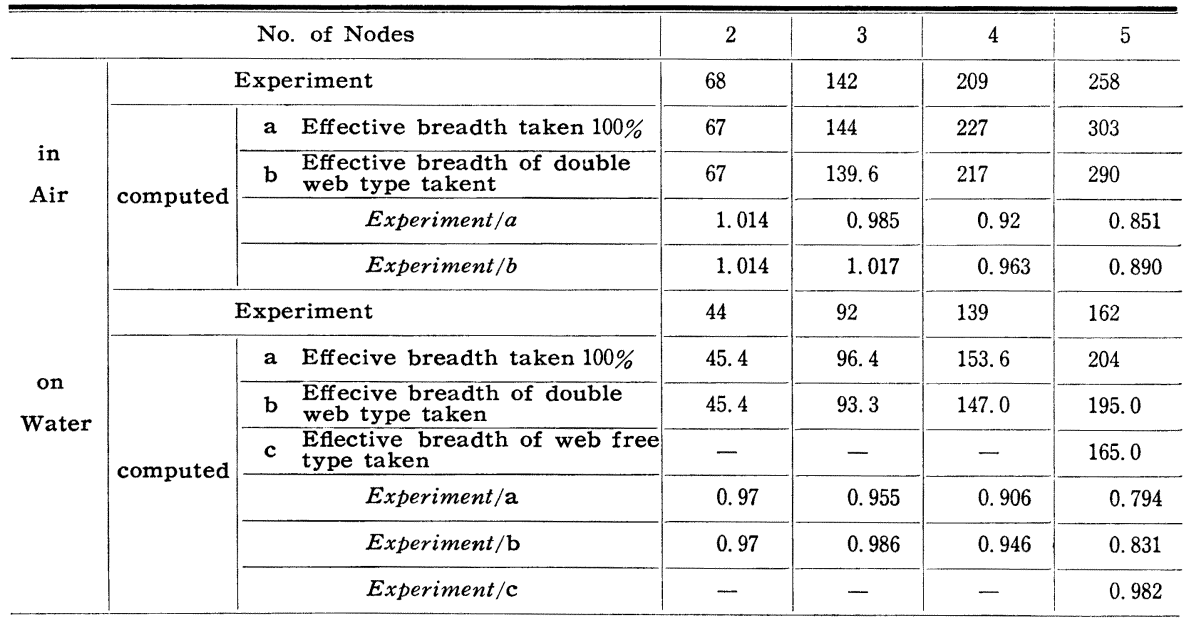

The results of frequency calculation using these rigidities are shown in Table 13. From this table we can conclude that the effecitve breadth have considerable influence upon the frequency. On this subject, however, much detailed analysis and experiments are necessary to establish the practical method and the detailed discussion is left to the future report.

\section{Conclusions and acknowledgement}

Frequency calculations were carried out for various type of ships, and the empirical coefficients were derived by the comparison of computed with measured value. Further the effects of ship parametres on the hull vertical frequency were studied and the following conclusions were drawn.

(1) Frequency prediction of various type of ships can be made with good accuracy, by means of electronic computer and the empirical coefficients shown in Table 5.

(2) The effect of rotational inertia upon the hull natural frequency is small and can be neglected for the ordinary type of ships.

(3) For the estimation of added virtual mass of 2-noded vibration, the Landweber's 2-parmetre family with Lewis 3-dimensional correction factor gives practically good result. The lengthwise distribution of 3-dimensional correction factor can be taken constant, as Prof. Kumai has pointed out.

(4) For the higher mode vibration the virtual mass has a tendency to decrease slightly, for practical use, however, it can be taken constant up to 4-node mode. For the minute investigation of virtual mass in the higher mode, more detailed experiment is necessary.

(5) Effective breadth has considerable effect on the hull natural frequency. To clarify this phe- 
nomenon quantitatively, furthr studies are necessary and open to the future report.

At the end the authors wish to experess tbeir hearty thanks to Prof. Watanabe and Prof. Kumai for kind guidance.

They are especially thankful to Prof. Yamakoshi for sincere leadership and detailed discussion on this report.

They are also indebted to Mr. Kimura who has cordially assisted in doing many numerical computations.

\section{References}

(1) Ohtaka, K., F. Hibino and M. Ohji, “A Study of Vertical Vibration of Ships. (1st rep.)" Journal of Society of Naval Architects of Japan. Vol.116, Dec. (1965)

(2) Leibowitz, R.C., "Theory of Freely Vibrating Nonuniform Beams, Including Methods of Solution and Application to Ships”. David Taylor Model Basin, Rep 1317, May, (1961)

(3) Vreugdenhil, C. B., "Natural Frequencies of Free Vertical Ship Vibrations".

(4) De Vries, J., "Numerical Calculation of Vertical Hull Vibration of Ships by Descretizing the Vibration System”. International Shipbuilding Progress, Vol.11. No. 118, June, (1964)

(5) Robinson, D.C., "Vibration Characteristics of NS Savannah". Report for 1st Conference on Ship Vibration, Jan. (1965)

(6) MC Goldrick. R. T. and V.L. Russo, "Hull Vibration Investigation on SS Gopher". Trans. S. N. A. M. E. (1955)

(7) Dutton. G. W. and R. C. Leibowitz, “A Procedure for Determining the Virtual Mass J-factors for the Flexural Modes of Vibrating System”. David Taylor Model Basin, Report 1623, Aug. (1962)

(8) Yamakoshi, M. and S. Ohnuma, “On the Coupled Vibration of ship Bottom -with Main Hull”. Journal of Society of Naval Architects of Japan, Vol.118, Dec. (1965)

(9) Landweber, L. andM. C. deMacagno. "Added Mass of Two-Dimensional Forms Oscillating in a Free Surface. "Journal of Ship Research, Mar, (1959)

(10) Lewis, F.M., “The Inertia of Water Surrounding a Vibrating Ship". Trans, S. N.A.M.E.

(11) Prohaska, C. W., "Vibrations Verticales du Navire."

(12) Landweber, L. and M. Macagno, “Added Mass of a three Parametre Family of two-Dimensional Forms Oscillating in a Free-Surface”. Journal of Ship Research, Mar. (1959)

(13) Kumai, T., "On the 3-Dimensional Correction Factor for the Virtual Inertia Coefficient in the Vertical Vibration of Ships I (J-Value of elliptic cylinder). Journal of Society of Naval Architects of Japan, Vol.112, Dec. (1962)

(14) Kumai, T., "On the Three-Dimensional Correction Factor for the Virtual Inaertia Coefficient in the Vertical Vibration of Ships II (On the Local Reduction Factor)". Vol.113 June, (1963)

(15) Burrill, L. C., W. Robson and R. L. Townsin. “Ship Vibration Entrained Water Experiments". Proceedings of the R.I.N.A.

(16) Schade, H, A., "The Effective Breadth of Stiffened Plating under Bending Loads". Trans SNAME Vol. 59. (1951)

(17) Schade, H.A., "The Effective Breadth Concept in Ship Structure Design". Trans. SNAME Vol.61. (1953) 